\title{
Between dependence and deprivation: the interlocking nature of land alienation in Tanzania
}

\begin{abstract}
:
Studies of accumulation by dispossession in the Global South tend to focus on individual sectors, e.g. largescale agriculture or conservation. Yet smallholder farmers and pastoralists are not affected by one process in isolation, but by multiple processes of land alienation. Drawing on the case of Tanzania, we illustrate the analytical purchase of a comprehensive examination of dynamics of land alienation across multiple sectors. To begin with, processes of land alienation through investments in agriculture, mining, conservation and tourism dovetail with a growing social differentiation and class formation. These dynamics generate unequal patterns of land deprivation and accumulation that evolve in a context of continued land dependency by the vast majority of the rural population. Consequently, land alienation engenders responses by individuals and communities seeking to maintain control over their means of production. These responses include migration, land tenure formalization and land transactions, and in turn propagate across multiple localities and scales, interlocking with and further reinforcing the effects of land alienation. On the whole, localized processes of primitive accumulation contribute to a scramble for land in the aggregate, providing justifications for policies that further drive land alienation.
\end{abstract}

Keywords: land grabbing, agriculture, conservation, accumulation by dispossession, Tanzania

This is the author manuscript accepted for publication and has undergone full peer review but has not been through the copyediting, typesetting, pagination and proofreading process, which may lead to differences between this version and the Version of Record. Please cite this article as doi: 10.1111/joac.12271

This article is protected by copyright. All rights reserved. 


\section{INTRODUCTION}

It appears that Tanzania is now facing a potential crisis of internal displacement in which people are shunted from place to place as valuable natural resources are appropriated from communities for conservation, commerce, and increasingly both together (Igoe \& Croucher, 2007, p. 553).

There has been significant attention to the so-called African land rush (Hall, Scoones, \& Tsikata, 2015; Scoones et al., 2013; Wolford et al., 2013), that is, the surge of foreign agricultural investments in Africa that started in the early 2000s. Many see Tanzania as an ideal country for large-scale agricultural land investments due to its record of liberal economic reforms and high growth rates in the last two decades. Tanzania's government has actively embraced this international interest in its land through the introduction of investment-friendly policies and institutions. The Tanzania Investment Centre was created in 1997 to facilitate foreign (and domestic) investments in, among other things, land. Several attempts were undertaken at creating a land bank of demarcated, titled and investment-ready tracts of land with agricultural potential. In 2009, the Government of Tanzania launched the 'Kilimo Kwanza' - or 'Agriculture First' - initiative aiming to modernize the agricultural sector through public and private investments. Shortly thereafter, Tanzania's president at the time - Jakaya Kikwete - launched the Southern Agricultural Growth Corridor of Tanzania (SAGCOT) initiative at the 2010 World Economic Forum Africa summit. In the SAGCOT investment blueprint, Kikwete asserted the official and widely circulated government position that 'Tanzania has immense opportunities for agricultural development. There are 44 million hectares of arable land, only 24 percent of which is being utilized. ... [T]he country's huge agricultural potential remains unutilized' (SAGCOT, 2011).

This article is protected by copyright. All rights reserved. 
This classic narrative of 'unused land' also circulates in other parts of the African continent and dovetails with a discourse of neoliberal economic development and growth through land tenure formalization, modernization and commercialization of agriculture and animal husbandry (Geisler, 2012; Lunstrum, 2016; Nalepa, Short Gianotti, \& Bauer, 2017). However, the narrative is at odds with continual reports of land conflicts across Tanzania. Drivers of such conflicts are many and include stalled or entirely failed land deals in large-scale agriculture, growth in human and livestock populations, patterns of displacement and migration, various conservation and tourism initiatives, infrastructure development, domestic land acquisition for speculation and cultivation, land tenure formalization and tree-planting initiatives, mining and so forth. Indeed, against official narratives of 'unused land', government authorities have threatened land owners of large estates with expropriation, accusing them of not properly 'developing' the land, calling for their property to be given back to poor or landless farmers in light of widespread land conflicts across the country (Guardian, 2016b; DailyNews, 2013). The narrative of 'unused land' is also questionable in light of growing concerns raised by Tanzania's environmental-conservation complex (see Brockington, 2006) over an allegedly growing number of incursions by pastoralists into national parks and game reserves (Shekighenda, 2016; MNRT, 2016).

In this article ${ }^{1}$, we go beyond exclusive attention to the agriculturally driven African land rush. Instead, we create an overview of the totality of land alienation processes in Tanzania by focusing on investments in agriculture, mining, conservation and tourism. Given their mutual reinforcement, these different processes should not be studied in isolation (Lunstrum, Bose, \& Zalik, 2016; Hall, Hirsch, \& Li, 2011; Hunsberger et al., 2017). We show how land alienation processes take place in a context of continued land dependency by

\footnotetext{
${ }^{1}$ This article is based on an extensive reading and analysis of relevant literature, decades of cumulative research experience on land issues and years of field presence in rural areas across several of Tanzania's regions, including Dodoma, Iringa, Manyara, Mbeya, Mtwara, Lindi, Kigoma, Arusha and Ruvuma.
}

This article is protected by copyright. All rights reserved. 
Tanzania's rural population and how these processes are reinforced by a growing social differentiation and class formation. We also show how rural people respond to land alienation and dispossession to maintain their means of production, such as through migration, land tenure formalization and land transaction, and how these responses, in turn, further reinforce the effects of land alienation. We provide important evidence to policy debates about land in Tanzania and elsewhere, thereby countering paradoxical claims over 'unused' or 'undeveloped' land amidst growing pressures on rural livelihoods by various drivers of land alienation.

\section{AGRARIAN CHANGE AND LAND ALIENATION}

Our contribution speaks to debates on agrarian change (Bernstein, 1977; Moyo, 2008; Li, 2014) and primitive accumulation, what Marx famously coined a 'historical process of divorcing the producer from the means of production' and enabling the appropriation of this freed labour for capitalist production (Marx, 1976, p. 875). David Harvey and many scholars after him built on this historical and still ongoing process of land enclosures in demonstrating how capitalism continues expanding its reach, creating new markets and property regimes, and changing social relations in the process of accumulation by dispossession (Harvey, 2003; Glassman, 2006; Hall, 2013).

\section{Different forms of land alienation}

Accumulation by rural dispossession takes many forms. It requires neither changes in formal property rights nor physical land grabbing by 'extra-economic means' (Akram-Lodhi, 2007; Hall, 2013). Rather, dispossession can be the result of more subtle processes of land control grabbing (Margulis, McKeon, \& Borras Jr, 2013; Peluso \& Lund, 2011) whereby access to use land for certain purposes is restricted.

This article is protected by copyright. All rights reserved. 
Conservation interventions, commodification of seeds ${ }^{2}$, contract farming, juridical capture, land use planning and demarcation, and land transactions can all result in land control grabbing (Bluwstein \& Lund, 2018; Stein \& Cunningham, 2017; Borras Jr, \& Franco, 2012; Huggins, 2014; Oya, 2012; Prudham, 2007). While none of these processes necessarily imply formal challenges to local land rights, they can have an effect similar to implying the loss of land altogether (Cáceres, 2015). Furthermore, accumulation by dispossession does not only involve the expropriation of land into private hands. It can also involve the transferral of customary or communal land ownership into the public domain (e.g. a national park), if third party interests (such as conservation NGOs or tourism investors) can profit via this act of enclosure (Kelly, 2011).

Accumulation by dispossession can also involve the appropriation of labour of those who lose their landbased means of production. However, in the Global South and specifically in the Tanzanian context the appropriation of surplus labour through proletarianization - what could be called labour grabbing (Stein \& Cunningham, 2017) - is limited to informal sectors where casual labour under highly exploitative arrangements is common (Mueller, 2011). Current patterns of land appropriation create only few formalized wage-labour opportunities (Meagher, 2016). Put differently, there may be no 'proletarian future' for landless or land-deprived people in many parts across the Global South (Li, 2011, p. 296). Thus, many smallholders join the ranks of a growing landless labour reserve (in the Marxian sense), that is, they are rendered a surplus population without a prospect for employment (Li, 2010; Ferguson, 2013; Peters, 2013). Shivji (2009) conceptualizes this process of accumulation by dispossession in the Tanzanian context as a 'disarticulated' accumulation, introduced through colonial or neoliberal regimes, and perpetuated by

\footnotetext{
2 'Tanzanian farmers are facing heavy prison sentences if they continue their traditional seed exchange' http://www.mo.be/en/analysis/tanzanian-farmers-are-facing-heavy-prison-sentences-if-they-continue-theirtraditional-seed
} 
the state's disregard for the peasantry. Indeed, Marx's concept of primitive accumulation rests on the integration of the new labour force into circuits of capitalist production, which is a deeply transformative process (Wood, 2002; Glassman 2006). In Tanzania, this process is ongoing and incomplete. Moreover, accumulation and dispossession are entangled with patterns of internal class formation, social differentiation and social reproduction (Mueller, 2011; Greco, 2015; Chung, 2017). In the course of various processes of land (control) and labour grabbing, societies become stratified into (predominantly male) landlords and owners of large livestock herds who can extract rents and surplus labour, and land-deprived farmers (especially women) and impoverished pastoralists who must offer their labour, struggling to survive. These agrarian transformations are not new to Tanzania (e.g. see Shao, 1986; von Freyhold, 1979; Iliffe, 1979) and continue even when recent foreign-led large-scale land deals stall, or entirely fail to materialize (Oya, 2013; Hall, 2013).

In response to the growing land squeeze underpinned by different forms of land (control) or labour grabbing, rural people turn to migration, or occupation of land enclosed as protected area (Charnley, 1997; Moyo \& Yeros, 2005; Hall, Hirsch, \& Li, 2011; Hall, 2013). Migration can create new forms of exclusion and increase land pressure elsewhere in the country where the arrival of migrants may contribute to land tenure formalization, as residents seek to protect their land against newcomers, whom they may be inclined to evict. Hall, Hirsch, and Li (2011) refer to this interlocking nature of different processes of land alienation as primitive accumulation 'from below'. Another response in the face of land alienation is livelihood diversification (Mueller, 2011; Hodgson, 2001). Socio-economic diversification can be underpinned by production declines in agriculture or livestock husbandry (Ponte, 2001; McCabe, Leslie, \& DeLuca, 2010) and tends to increase social differentiation and to promote informal sectors of wage labour (Peters, 2004; Bryceson, 2002; Lyimo, 2014). 


\section{Tanzania, a land-dependent nation}

Agriculture in Tanzania can be broadly characterised by a stagnant agricultural labour productivity (Korotayev \& Zinkina, 2015), and since the 1990s a growing number of studies have reported a declining soil fertility (Ponte, 2001; Baijukya et al., 2005; Lindberg, 1996; Kangalawe, Christiansson, \& Östberg, 2008; Snyder 1996). This development was initiated by ill-conceived and coercive resettlement policies of the 1970s (villagization) that led to agricultural intensification (Shao, 1986; Kjekshus, 1977). It was compounded by structural adjustment and liberalization policies of the 1980s and 1990s, which deprived a growing number of smallholders of agricultural inputs necessary to maintain or increase production (Bryceson, 2002). Lokina et al. (2011) report that with the exception of rice, average yields of maize, sorghum and beans - key food staples - declined in the 2000s, and total output could be stabilized only through agricultural area expansion. FAO highlights that 'with the exception of rice, the country has ... remained a net importer of food staples during the period 2007-2013'. FAO attests that Tanzania has 'one of the lowest levels of productivity in sub-Saharan Africa' due to a lack of irrigation, improved seeds and fertilizers (FAO, 2014 , p. 1). Coulson (2013) points out that the present growth in agricultural outputs (around $4 \%$ per year) exceeds population growth (around $3 \%$ per year), yet he is sceptical that this level of growth (which is largely based on agricultural area expansion) can be maintained in the future. The competition for farmland across many parts of Tanzania is therefore set to increase.

Despite ongoing processes of deagrarianization or depeasantization (Bryceson, 2002) that echo social differentiation and socio-economic diversification, we contend that Tanzania's growing peasantry remains highly dependent on land and environment. A majority of income for rural livelihoods across sub-Saharan Africa and specifically in Tanzania is sourced from agriculture, livestock, environmental resources (forest and non-forest) or casual labour on other people's farms. Land and environmental dependency cuts across 
wealth, gender and education, although poorer, less-educated and female-headed households tend to be more dependent (Angelsen et al., 2014; Lund \& Treue, 2008). Tanzania's population is expected to reach 137 million in 2050, having already grown from 10 to 53 million people in 1960-2015 (Figure 1) 3 $^{3}$ While Tanzania has seen substantial macroeconomic growth of late, the country remains a predominantly agriculture-based smallholder economy (Korotayev \& Zinkina, 2015). Industrialization has been limited and uneven, and economic growth has not resulted in greatly expanded opportunities for formal employment (Wuyts \& Kilama, 2016; Gray, 2013). While rural-urban migration will continue to shift the Tanzanian demographic landscape in the coming decades, in absolute terms more people will likely have to live off the land in the future. In the absence of mass industries that provide employment opportunities (Wuyts \& Kilama, 2016), urbanization and deagrarianization will not change the fact that land and land-based resources will remain the main means of (re)production for tens of millions of smallholders in the foreseeable future (see also Moyo \& Yeros, 2005; Hall, Hirsch, \& Li, 2011).

\section{[FIGURE 1 HERE]}

Figure 1: Population growth in Tanzania (recorded until 2015, estimated beyond 2015, source: World Bank Health, Nutrition and Population Statistics)

To further contextualize Tanzanian dynamics of agrarian change and land alienation, we present findings from two studies conducted across Tanzania by some of the authors of this article. The research project "Transformations in Poverty and Property Rights in Rural Tanzania" ${ }^{4}$ randomly sampled 1,600 households in 33 villages between 2010 and 2016, yielding average rates of landlessness (understood as owning 1 acre of land or less per household) from 9.4 to $22.2 \%$ across the regions Kigoma, Mbeya/Songwe, Manyara and

\footnotetext{
${ }^{3}$ World Bank Health Nutrition and Population Statistics, accessed 2017.04.27

${ }^{4}$ https://www.udsm.ac.tz/node/492
} 
Dodoma. This range illustrates the geographically uneven effects of different drivers of land alienation as they intersect with population density and growth, and local land markets. Another, larger dataset, collected under the auspices of a research project on rural livelihoods and conservation ${ }^{5}$, illustrates that landlessness is also thoroughly gendered. Based on a sample of 945 female- and 1,924 male-headed households interviewed in 2014-15 across the regions Arusha, Manyara, Ruvuma and Lindi, female-headed households evince a fourfold prevalence in being landless (following the same definition as above). In the following sections we illustrate how in the context of continued rural land dependency, and an uneven and gendered geography of landlessness, different drivers of land alienation interlock and jointly advance an ongoing and yet incomplete primitive accumulation.

\section{GOVERNANCE OF LAND IN TANZANIA}

From colonial rule Tanzania inherited a system of state-sanctioned land alienation through land laws (URT, 1994). From a legal perspective, all land in Tanzania is public land, vested in the president as trustee for and on behalf of all Tanzanian citizens. Three overarching land categories are defined to govern land use and land control: reserved land, village land and general land. General land includes urban areas and large-scale investments. It falls directly under the Commissioner for Lands, and is defined in Land Act No. 4 as 'all public land which is not reserved land or village land, and includes unoccupied or unused village land' (URT 1999, p. 10, our emphasis). General land is therefore an ambiguous residual land category for lands that either are not clearly categorized otherwise (Sundet, 2005), or can be claimed as 'unused', 'unoccupied', 'undeveloped', etc. Such claims are enabled by the lack of a national cadastre and inaccurate and disputed

\footnotetext{
${ }^{5}$ https://www.ucl.ac.uk/pima/
} 
records of village and reserved land boundaries, and they are generally underpinned by unequal power relations that render migrants, women and pastoralists particularly vulnerable (Odgaard, 2002).

Reserved land is governed by various statutory bodies. Forest reserves are for example governed by the Tanzanian Forest Service in accordance with the Forest Act 2002. The vast majority of reserved land in Tanzania is set aside for conservation and tourism purposes. Village land is governed by democratically elected village councils under the Village Land Act No. 5 of 1999. The act formally recognizes customary land rights and has legal provisions to prevent discrimination against women and vulnerable groups. Smallholders are encouraged to further secure their land rights by obtaining certificates of customary rights of occupancy (CCROs), and male-headed households are encouraged to register land titles jointly with their wives (Odgaard, 2006), yet progress towards more equitable land registration is slow (Pedersen, 2015). For instance, only 3.4\% and 5.8\% of issued CCROs in Babati and Bariadi Districts were jointly received by a man and his wife (URT, 2010). Preliminary results from a 2014-2016 study show similar trends across the districts Chamwino, Kongwa and Kasulu. On average, $11.4 \%$ of CCROs were held jointly by a man and a woman (Askew \& Odgaard, in review). Through CCROs, rural people are expected to avoid land disputes, increase agricultural productivity, and become integrated in the formal banking sector, with the CCRO acting as collateral to receive a loan. CCROs are technically not to be issued before the village has obtained a certificate of village land (CVL) from the Commissioner of Lands, which is conditioned upon the successful surveying and demarcating of village boundaries, an approved village land use plan (VLUP) and a village registry (Stein et al., 2016) ${ }^{6}$.

\footnotetext{
${ }^{6}$ According to the 2016 National Land Policy draft, out of roughly 12,500 villages (nobody really knows the exact number), $80 \%$ have their boundaries surveyed and $13.1 \%$ have a village land use plan (URT, 2016a).
} 
Village land use planning (VLUP) has attained a prominent role in land tenure formalization policies that aim to identify 'freely available' and 'unoccupied' village land for large-scale agricultural investment or community-based conservation. VLUP exercises invite several actors to influence the process: they are sometimes facilitated by outsiders interested to acquire land, and they must be reviewed by district land and planning officers before approval by the National Land Use Planning Commission is sought (Walwa, 2017). While ostensibly aimed at secure land rights and empowerment for village communities, VLUP processes have, in practice, resulted in physical or economic displacement and reinforced the very same farmer-herder conflicts that they proclaim to mitigate (Walwa, 2017). VLUP processes have been observed to enable a shift of authority into the hands of political-bureaucratic and economic elites, and have furthered land alienation at the expense of both farmers and pastoralists in favour of investments in commercial agriculture, conservation and tourism (Stein \& Cunningham, 2017; Greco, 2016; Maganga et al., 2016). Farmers and pastoralists who are deemed migrants are particularly vulnerable to be rendered landless through VLUP exercises that do not recognize their residency in the village (Walwa, 2017; Bluwstein, 2017). Pastoralists with recognized claims are also vulnerable in land use planning exercises that fragment rangelands (Goldman \& Riosmena, 2013), or result in limitations of livestock mobility to particular districts or villages (usually through branding of livestock) and/or forced sales of 'excess cattle' (URT, 2013b, p. 193). The practice of land use planning therefore challenges provisions under the Land Acts that aim to protect people's customary land rights by recognizing their claims to village land vis-à-vis external investors, even when smallholders do not have a title or other forms of registration. When village land is acquired by outsiders under a granted right of occupancy that is governed by statutory law, local people's customary land rights and land claims can be overridden, because 'unequal power relations lead to unequal recognition of customary and statutory law' (Locher, 2016, p. 393). 
Given the evidence so far, it is therefore not surprising that the promises of land tenure formalization have been elusive, even in cases of counter-mapping of communal resources by local people (Maganga et al., 2016; Stein et al., 2016; Hodgson \& Schroeder, 2002). Importantly, once land has been identified for investment through village land use planning exercises, the land undergoes a legal shift out of village land status and village control to general land status and control by Tanzanian Investment Centre (TIC). TIC secures a Certificate of Occupancy for the land and in turn subleases it to the investor for up to 99 years. Consequently, power over land control shifts from village to TIC (central government), regional authorities and foreign investors, and it remains in these hands even if the investment does not materialize. A draft of the 2016 National Land Policy proposes to limit leases to 33 years (URT, 2016a, p. 41) but suggests to allow investors to purchase 'Unit Titles' in village lands that would further facilitate land alienation through highly capitalized investment (URT, 2016a, p. 40-1). Therefore, we contend that dispossession by formalization continues to be inscribed in official land policies from the outset, rather than being an unintended outcome.

Having situated the dynamics of agrarian change in the contemporary context of land governance through land use planning and land formalization in Tanzania, we now present evidence of the multiple drivers of land alienation, starting with investments in commercial agriculture, continuing with mining and finishing with conservation.

\section{INVESTMENTS IN COMMERCIAL AGRICULTURE}

Table 1 provides a historical overview of land alienation through commercial agriculture and ranching. The statistics reflect a poor state of information, showing an inconsistent and at times conflicting picture (URT, 1994; Sulle, 2015). Official data suggests that $1.5 \%$ of Tanzania's terrestrial land is under commercial large-

This article is protected by copyright. All rights reserved. 
scale investments (>100 ha) and $6.6 \%$ under medium-scale farming (5-100 ha, see Table 1$)$. Locher \& Sulle (2014) estimated around $10,000 \mathrm{~km}^{2}$ of new land deals above 200 ha by foreign investors ${ }^{7}$ for agricultural production $^{8}$ at the height of the land rush by the end of 2012. Locher and Sulle emphasize that only ten deals with a total area of $1,450 \mathrm{~km}^{2}$ can be considered concluded. Focusing on agro-fuel investments since 2003, Abdallah et al. (2014) identified 32 mostly foreign investors that had requested a total of $11,000 \mathrm{~km}^{2}$ of land above 2,000 ha. Yet only nine investors acquired land, totalling $2,000 \mathrm{~km}^{2}$. A majority have gone bankrupt or have shifted to food production and are still struggling to become operational.

The recently updated Land Matrix database covers recent deals ('contract size') amounting to $2,725 \mathrm{~km}^{2}$, considerably less than initially reported (Table 1). These deals correlate geographically with the SAGCOT (Southern Agricultural Growth Corridor of Tanzania) designation (Figure 2). The SAGCOT initiative envisages the development of 350,000 ha of land into large-scale agriculture and 330,000 ha into outgrower schemes within the corridor (SAGCOT, 2011; NewAlliance, 2014). This would entail the re-categorization of village into general land, which is a declared objective of the SAGCOT initiative. In a 2012 presentation aimed to advertise the SAGCOT initiative to potential investors, the Minister of Lands, Housing and Human Settlement indicated that around $9,000 \mathrm{~km}^{2}$ of village land in the SAGCOT corridor had already been identified ('freed up') for potential investments based on a review of village land use plans (MLHS, 2012).

\section{[Table 1 here]}

Table 1: Land under alienation through commercial agriculture in Tanzania

\footnotetext{
${ }^{7}$ Or in collaboration between foreign and domestic investors.

${ }^{8}$ Including food, biofuels, timber plantations, and forestry carbon credits.
} 


\section{[FIGURE 2 here]}

Figure 2: SAGCOT (2011) and land deals for large-scale agriculture in Tanzania (Landmatrix, 2016)

In addition to foreign-led investments, smaller land deals and leases by domestic investors for investments in agriculture or forestry are taking place in different parts of the country (Olwig, et al. 2015). In a commissioned study for the Ministry of Lands, Housing and Human Settlement, the University of Dar es Salaam evaluated agricultural land-holdings ( $>50$ acres) in mainland Tanzania in 2013 (URT, 2013a). Out of a purposive sample of 691 farms covering 3,651 $\mathrm{km}^{2}$ across Tanzania, ownership of 666 farms could be determined. Tanzanian individuals owned by far the most farms (455), followed by Tanzanian companies (72). However, given the differences in average farm area between domestic and foreign property owners, proportionately few foreign individuals and companies (45 out of 666 ) owned more than a quarter of all sampled land area (Table 2).

\section{[TABLE 2 here]}

Table 2: Farm ownership and size, compiled based on URT (2013a)

Table 2 may already reflect a growing urban class of Tanzanian elites who drive investments in mediumscale commercial agriculture, seeking to reinvest their wealth in land (Jayne et al., 2016). Official Tanzanian statistics indicate that $28 \%$ of urban residents are engaged in agricultural activities (NBS, 2014). Jayne et al. (2016) report a rise in Tanzanian land ownership by urban households from 11.8 to $32.5 \%$ of national landholdings in only five years from 2005 to 2010. Within the same period, urban households increased 
their share of land from 17.2 to $78.9 \%$ of landholdings of 20 ha or above (Jayne et al., 2016). This development disproportionally affects rural women in negative ways (Knapman et al., 2017), may 'exacerbate land scarcity in rural areas' (Jayne et al., 2016, p. 197), and may also reconfigure social relations of property and labour. Land accumulation for production and speculation by urban elites is in some cases followed by the subsequent leasing of this land to the previous owners - often poor smallholders who cannot afford to cultivate their own land - who now find themselves as tenants working for the new landlords or co-owners. These gendered dynamics of class formation and labour grabbing tempted The Economist to blame the urban elites for 'Africa's real land grab' (Economist, 2016).

To conclude, attempted, successful and failed investments in large-scale land deals for agribusiness may all contribute to land alienation. Land tenure reconfigurations for medium-scale cultivation and speculation without any involvement of foreign investment constitute another important process of land alienation in Tanzania that is underpinned by and produces new dynamics of class formation and social differentiation. Importantly, agricultural investments - foreign or domestic - that do not materialize and might be excluded from statistics, can have severe impacts on land access and control for both farmers and pastoralists. Overlapping claims to land and subsequent conflicts abound around investments that are initiated with little regard for local context, legal pluralism and locally specific and gendered power relations around access to land. Since land must be acquired by the investor relatively early in the process, processes of resettlement, evictions or fencing happen in advance of production. If the investment implementation is delayed or abandoned, land is alienated from smallholders even though nothing is being produced by the investor (Engström, 2013; Maganga et al., 2016; Stein \& Cunningham, 2017). 


\section{MINING}

Mining has also increasingly affected land tenure in Tanzania in the past years. The government of Tanzania considers $90 \%$ of the country's terrestrial area $\left(800,000 \mathrm{~km}^{2}\right)$ as potentially having mining resources (URT, 2015). Recent estimates suggest that 680,000 people are engaged in artisanal mining in Tanzania, and another 15,000 in large-scale mining (URT, 2015; Bryceson \& Geenen, 2016). Although artisanal mining is dominated by men, local economies build around mining also attract women (Bryceson \& Geenen, 2016). In the wake of the 1998 Mining Act, which strongly promoted foreign direct investment, Tanzania has experienced a mining boom, and gold has become a major export commodity (Bryceson \& Jønsson, 2010; Schroeder, 2012). International mining companies' large-scale investments and extraction methods are barely taxed by the Tanzanian state ${ }^{9}$, generate little employment, have led to displacement of hundreds of thousands of artisanal miners, and have polluted the environments of farmers and pastoralists living close to mines (Emel, Huber, \& Makene, 2011; Kitula, 2006; Holterman, 2014; Schroeder, 2012; Magai \& Márquez-Velázquez, 2011). Tanzanian mining laws are ambiguous and vest much power in the Commissioner of Mining, while villagers have little say in mining concession allocations (Lange, 2008). Once minerals are discovered, mining laws take precedence over land laws, challenging existing customary land rights of rural people (Pedersen \& Jacob, 2017). At times, mining investors work with outdated maps, sweeping aside claims to land ownership and control by small-scale miners, pastoralists and farmers, and even entire villages (Kulindwa et al., 2003; Lange, 2008). The Geological Survey of Tanzania ${ }^{10}$ maps 482 mines across the country, including 125 gold mines. According to the national mining cadastre, an

\footnotetext{
${ }^{9}$ But see Pedersen \& Jacob (2017) for the most recent changes to Tanzania's mining legislation

${ }^{10} \mathrm{http}: / /$ www.gmis-tanzania.com/
} 
estimated total area ${ }^{11}$ of almost $140,000 \mathrm{~km}^{2}$ (15\% of Tanzania's terrestrial land area) is designated for prospect licenses for potential exploration (Figure 3).

Where mining interests collide with conservation and tourism interests, these geographic and economic intersections can lead to further expansion of conservation on village lands to compensate for mining activities in protected areas, as the example of Selous Game Reserve illustrates. Uranium mining in Selous was permitted on condition that the UNESCO World Heritage Site should not be reduced. Consequently, boundary changes to excise the mining area from the reserve have been proposed to include land outside the game reserve to compensate the losses to mining ${ }^{12}$. In return for potentially highly hazardous activities, the mining company is expected to support anti-poaching operations in and around the game reserve (Tairo, 2014). These novel intersections and alliances between conservation and mining interests can jointly challenge local land and resource control.

\section{[Figure 3 here]}

Figure 3: Different mining concessions in Tanzania, overlaid with an incomplete selection of protected areas. Screenshot from FlexiCadastre. Accessed 2017.01.10

\section{CONSERVATION}

Tanzania's colonial and post-colonial history is deeply intertwined with efforts to set aside land held in common as 'wilderness' areas for biodiversity conservation that would benefit tourism activities such as game viewing and hunting (Neumann, 1998). This fortress conservation approach (Brockington, 2002) was

\footnotetext{
${ }^{11}$ Own estimate, based on http://portal.mem.go.tz/map/

12 interview with Ministry official, November, 2016. UNESCO decisions and documents available at http://whc.unesco.org/en/decisions/4814, http://whc.unesco.org/en/list/199/documents/
} 
initiated towards the end of the 19th century by the German colonial occupation, continued under the British rule and after independence, and was supplemented by community-based conservation initiatives since the 1990s in the course of neoliberalization of conservation (Igoe \& Brockington, 2007). These two paradigmatic regimes of conservationist land control have produced an extensive network of protected areas (Figure 4). Since the late 1990s conservation approaches in the Global South have morphed into what big international NGOs and their donors call landscape conservation ${ }^{13}$, a claim to vast territories spanning different conservation interventions and protected area categories, ecosystems and habitats, people, villages and communities (Clay, 2016; Bluwstein, in review). In the following we show how large parts of Tanzania's territories are to different degrees taken out of local control and production through the advancement of different conservation regimes.

\section{Community-Based Forest Management}

The first community-based forest management (CBFM) schemes on village land were reserved in the 1990s and since then implementation has proceeded under donor financing (Lund et al., 2017). By 2012 a total of 1,233 villages were involved in CBFM and the area of village land under reservation was estimated at $23,667 \mathrm{~km}^{2}$ (URT, 2012b) ${ }^{14}$. This estimate also includes CBFM areas in various planning stages (Lund et al., 2017). In reality, the area where CBFM has changed smallholder's access to land and land-based resources may thus be much smaller. Yet, conservation 'work in progress' may also imply 'land alienation in progress'.

Through CBFM, village councils are granted administrative powers to manage and benefit from forest reserves on village land, while the state can no longer exploit them and waives all royalties generated from them (Blomley \& Iddi, 2009). However, with the reservation, village councils foreclose the possibility of

\footnotetext{
${ }^{13}$ E.g., AWF, WCS, WWF, FZS, TNC, USAID

${ }^{14}$ We do not mention Joint Forest Management (JFM) here as it only applies to reserved forests under state authority (see Table 3).
} 
changing land use away from it being a 'forest'. Farming and settlements are banned, as is grazing in some areas. This change in property relations and land control implies that the forest bureaucracy gets a permanent say in determining the land use, while the village councils lose the right to independently change it (Sungusia \& Lund, 2016). Yet, in terms of access to forest-based livelihoods, CBFM, in principle, enables villagers to exclude others, such as urban elites, from exploiting their forest areas. Villagers gain legal access to retain all benefits from the use of the forest under the constraint that it is managed in accordance with the Forest Act 2002. In practice, this access is curtailed by various other pieces of legislation and bureaucratic procedures (Sungusia \& Lund, 2016). Thus, it took 20 years since the initiation of CBFM in Tanzania before the first larger volume of timber was harvested in a CBFM forest and substantial revenues started flowing (Khatun et al., 2015).

Formalization of villagers' rights to access forests, but also the responsibility to maintain them, has led to restrictions, increased enforcement and policing of fellow villagers (Lund \& Treue, 2008; Vyamana, 2009). This has constrained and criminalized the livelihoods of poor and forest-dependent smallholders while giving a small elite of village-level forest managers the possibility of benefiting from allowances and associated income opportunities (Lund \& Saito-Jensen, 2013; Green \& Lund, 2015).

\section{Wildlife Management Areas}

Since the early 2000s, around 20 Wildlife Management Areas (WMAs) have been established on more than $30,000 \mathrm{~km}^{2}$ of village land across Tanzania. This has happened under the auspices of the Ministry of Natural Resources and Tourism, supported by various international donors ${ }^{15}$, and several international conservation NGOs, most prominently WWF, AWF, WCS and $\mathrm{FZS}^{16}$. A WMA consists of a contiguous village land area set

\footnotetext{
${ }^{15}$ E.g., USAID, Danida, GIZ, KfW, AFD, GEF/UNDP

${ }^{16}$ World Wildlife Fund, African Wildlife Foundation, Wildlife Conservation Society, Frankfurt Zoological Society
} 
aside by several neighbouring villages for wildlife conservation purposes. Often, WMAs are established in areas that are believed to serve connectivity or corridor functions for the movement of wildlife between core protected areas (Goldman, 2009). In WMAs, agriculture, settlements and, in some places, livestock grazing are banned or heavily restricted through village land use planning. Many other land-dependent activities, such as production of charcoal or the collection of firewood or construction materials, are also restricted or banned altogether. In return, villages are promised revenues from tourism investors who are invited to operate in WMAs under a contractual agreement with the community-based organization (CBO). $\mathrm{A} C B O$ jointly with a board of trustees ${ }^{17}$ manage the WMA on behalf of the member villages. The land administration powers bestowed on village councils by the Local Government Act of 1982 and reinforced with the 1999 Village Land Act No. 5 are thereby handed over to these newly established and weakly accountable institutions, resulting in often overly restrictive land use and management plans that foreclose alternative land use in WMA territories into the future (Bluwstein, Moyo, \& Kicheleri, 2016). CBOs are generally not willing to allow changes in WMA land use planning, and it is virtually impossible for dissenting communities or even entire villages to undo a WMA in practice, once it is established (Bluwstein \& Lund, 2018; Bluwstein, Moyo, \& Kicheleri, 2016). WMAs thus erode the progressive features of land reforms inscribed in the Land Acts of 1999.

In many instances, the implementation of WMAs has spurred land and boundary conflicts, evictions and displacement, despite the rhetoric of community-based participation and ownership. Restrictive WMA regimes tend to recentralize land and resource control with few employment opportunities in return (Benjaminsen et al., 2013; Green \& Adams, 2014). Female-headed households are particularly vulnerable to WMA interventions, especially if they are poor (Homewood, Nielsen, \& Keane, in review). Contrary to CBFM

\footnotetext{
${ }^{17}$ That includes district government representatives
} 
arrangements that allow village councils to protect village land against external interests and to keep revenues from resource use, in WMAs new actors - conservation NGOs, tourism investors and local economic and political elites - are invited to control village lands in the name of community-based conservation. This undermines elected village councils and leads to the emergence of new forms of authority over land control, while promoting elite capture of WMA benefits (Bluwstein, 2017).

There are a few cases where local residents have chosen to create a WMA to protect their land rights against actual or perceived outsiders who may want to establish themselves in these villages (Bluwstein, in review). Often the ones excluded are landless migrants searching for land, farmers in need to expand their activities but lacking inputs to intensify production, or urban or rural elites looking for capital investment opportunities. These cases of exclusion, too, tend to contribute to the growing land pressure across the country when communities or entire villages succeed in taking land out of production or investment.

\section{National Parks and Game and Forest Reserves}

Most of Tanzania's core protected areas (national parks, game and forest reserves) were initially declared many decades ago, often involving evictions (Brockington, Sachedina, \& Scholfield, 2008; Sunseri, 2009). However, their protection status and territories have not remained stable, implying recurring incidences of physical and economic displacement (Brockington \& Igoe, 2006). Displacement reconfigures the gendered intra-household dynamics in complex ways, in many instances creating new burdens for women, but to some extent also offering opportunities to renegotiate entrenched gender roles (Brockington, 2002). Many parks and reserves have consolidated or expanded their existing territories in the past decades, often animated by the landscape vision of conservation NGOs and their donors (Bluwstein, in review). With the introduction of GPS technology in the 2000s, several National Parks have resurveyed their boundaries, which led to new claims against adjacent villages (Boerstra, 2017; Sachedina, 2008). Calls to resettle rural 
people or to relocate entire villages in order to 'resolve' protracted boundary conflicts with protected areas are common and continue until this day. ${ }^{18}$

Similarly, forest reserves in Tanzania have been gazetted, expanded, diminished, or entirely degazetted over the past century since the German colonial period (Sunseri, 2009; Hurst, 2004). Furthermore, changing regulations and waxing and waning patterns of enforcement have implied that the role of forest reserves in rural livelihoods has been in constant flux. The forest reserve estate has grown throughout the postcolonial period, especially in the 1980s and 1990s (Hurst, 2004). Today, according to different sources, Tanzania features around $450-700$ forest reserves (see Table 3). Since the formation of the state agency Tanzania Forest Service in 2010, there has been an increased emphasis on revenue generation from forest reserves, which has led to more enforcement and evictions, as well as to renewed efforts to re-establish firm reserve boundaries. Thus, rural people who in the past benefited from access to poorly defined, demarcated and enforced reserve boundaries now find themselves under increasing scrutiny and policing.

\section{Hunting concessions}

There are around 140 hunting blocks in Tanzania. A hunting block is neither a protected area nor a land category, but a concession to hunt in a bounded area inside a core protected area (Game Reserve, GR), a Game Controlled Area (GCA), an Open Area (OA) or a Wildlife Management Area (WMA). GCAs and OAs have overlapped with communal lands since their establishment during colonial rule. The Wildlife Division of the Ministry of Natural Resources and Tourism can allocate a hunting block within a GCA or an OA, thereby challenging game viewing tourism activities on village lands that may have been established with the approval of village governments. The Wildlife Division favours professional hunting outfitters' interests

\footnotetext{
${ }^{18}$ E.g. nine villages adjacent to Ruaha National Park are to be „removed completely”. IPP Guardian, 2017.06.15 http://www.ippmedia.com/en/news/act-environmental-degradation-samia-orders-dcs
} 
against the interests of village governments because - unlike game viewing activities - hunting concessions directly fund the Ministry's coffers, and rents can be captured directly by Ministry officials (Benjaminsen et al., 2013). However, OAs are not codified as a land category in land or wildlife laws. Similarly, many GCAs de jure also ceased to exist as a land category after the 2009 Wildlife Conservation Act declared that GCAs cannot overlap with village lands (URT 2009, $\$ 16(5)$ ). Nonetheless, until this day the liminal category of GCAs - more so than of OAs - is used to assign hunting blocks against the will of village councils (Gardner, 2016) or to impose restrictions on settlement and livestock keeping (URT, 2013b). GCAs and OAs continue to be invoked in official government and NGO reports and statistics (URT, 2013c; UNEP-WCMC, 2017). If villages are opposing the often highly restrictive hunting operations on their lands (Wright, 2016), the Wildlife Division might impose a false choice on village governments to either accept a restrictive WMA scheme or to see their land being reassigned as exclusive hunting grounds under a GCA or a GR regime, as the long-standing and ongoing conflict in Loliondo demonstrates (Gardner, 2016).

Most hunting blocks are controlled by foreigners (MNRT, 2006), and some are directly linked to ultra-rich US or Arab oligarchs or Asian-Tanzanian nationals (Wright, 2016), whose wealth and exclusive access to government authorities can corrupt individuals at all levels of government down to elected village officials (Packer 2015). The US-based Friedkin Conservation Fund alone claims an area of 6.1 million acres $(24,685$ $\mathrm{km}^{2}$ ) - $2.8 \%$ of Tanzania's terrestrial area - for conservation and tourism through exclusive hunting, game viewing and lodging ${ }^{19}$. Hunting concessions on village lands are often subleased to other hunting operators (Packer, 2015) or even to mining companies (Noe, 2013) without any say by the village governments, whose land is traded as a commodity between private investors for significant sums of money, with negligible compensation for the villages (Kisembo, 2012).

\footnotetext{
${ }^{19} \mathrm{http} / / /$ www.tgts.com/philanthropy/
} 
In sum, foreign and domestic interests in tourism, wildlife and forest conservation constitute the major immediate driver of land tenure change and land alienation in Tanzania. By comparing the most authoritative yet incomplete and inaccurate sources, we conclude that around $42 \%$ of Tanzania's total terrestrial area is already enclosed for different forms of conservation (Table 3, Figure 4$)^{20}$. Taking into account the widespread boundary uncertainties, overlapping claims and different data sources, we provide a range of $39.5-51.4 \%$.

This estimate differs significantly from often-repeated official statistics about land distribution in Tanzania. A recent draft of the National Land Policy, for instance, gives the impression that there is plenty of village land and underplays the extent of conservation enclosures by stating that 'village land is estimated to be 70 percent, general land 2 percent and reserved land which includes forest and wildlife sanctuaries is 28 percent' (URT, 2016a, p. 19). Such misleading statistics become even more problematic if we also consider the many more WMAs that are currently planned across Tanzania ${ }^{21}$. If realized, Tanzania could claim to protect $50 \%$ or more of its terrestrial area in the name of conservation and tourism ${ }^{22}$. We do not think that all WMAs will be implemented as envisioned due to a) local resistance (e.g. Loliondo and Simanjiro), b) lack of investment interest (in most southern and western areas), or c) too ambitious spatial planning (e.g. Lake Natron). However, the planning process in itself raises serious concerns over land alienation (Gardner,

\footnotetext{
${ }^{20}$ There is no single accurate dataset of protected areas in Tanzania, but different organizations keep their own records, which they sometimes share with each other. Because many protected areas are in the process of being upgraded or resurveyed, or their boundaries remain poorly known to conservation authorities, any available datasets can show only an outdated, incomplete and inaccurate snapshot. To counter this, in Table 3 we provide a spatial range of the total amount of land that is likely claimed for conservation. Our estimate builds on the World Database on Protected Areas (WDPA, accessed 2017.01.11) and improves it by avoiding double counting and by including a number of known protected areas that are missing in WDPA. WDPA shows an area of around $361,000 \mathrm{~km}^{2}$ under different forms of protection, yet it includes double counting, its WMA coverage is incomplete, and CBFM areas are entirely excluded.

${ }^{21}$ Different sources suggest a total of 38 or 39 WMAs to be eventually established on $125,000-136,714 \mathrm{~km}^{2}$ (Sosovele, 2015; Mayeta, 2016)

${ }^{22}$ An accurate estimate is impossible, because some WMAs would replace some of the existent GCAs
} 
2012). It is due to such contestations around planning and territorial claims in the name of conservation, that we do not provide one fixed estimate for total land under conservation, but rather offer a corroborated estimate on the spatial extent of conservation claims. The widespread and vast boundary uncertainties, overlaps and discrepancies among different data sources constitute a major driver of land conflicts, as rural communities have little say over the maps that prescribe whether people's actions and resident status are lawful or not (Bluwstein \& Lund, 2018).

\section{[Figure 4 here]}

Figure 4: Conservation territories in Tanzania. GIS shapefiles sourced from the recent WDPA dataset (see Table 3) and several known protected areas that are missing in WDPA (7 GRs, 4 WMAs, 1 FR; source: WWF \& TAWIRI shapefiles). CBFM is not mapped for lack of geodata.

This article is protected by copyright. All rights reserved. 
[Table 3 here, landscape format if necessary]

TABLE 3: Territories under different forms of conservation in Tanzania ${ }^{23}$

\footnotetext{
${ }^{23} \mathrm{~T}$ : Tourism allowed. L: Local Livelihoods fully prohibited. na: not available
}

This article is protected by copyright. All rights reserved. 


\section{THE INTERLOCKING NATURE OF MULTIPLE DRIVERS OF LAND}

\section{ALIENATION}

Many current land tenure conflicts are remnants of past processes of land alienation (Nelson, Sulle, \& Lekaita, 2012; Sundet, 1997; URT, 1994). With the onset of colonial rule, agro-pastoral communities saw their territories diminished by land reservations and commercial agriculture, and were forced into less fertile territories with a lack of water resources for agricultural and livestock production (Neumann, 1998; Hodgson, 2001). Colonial land alienation gave way to policies of post-colonial villagization through resettlement and the nationalization of land through parastatals in the 1970s (Sundet, 1997; Shivji, 1998). Land alienation policies were again reconfigured during the transition from post-colonial socialism towards liberalization in the 1980s and 1990s, when large swaths of communal lands were appropriated for agriculture, tourism and mining (Igoe \& Brockington, 1999; Richter, 1994; URT, 1994).

The history of dispossession is as complex as it is contested. For instance, large-scale agricultural investments through parastatals such as the National Food and Agricultural Corporation (NAFCO) displaced many smallholders and pastoralists. Later these people would be blamed for 'invading' alienated lands (Chachage \& Mbunda, 2009). After many parastatal companies had been dismantled and privatized by the late 1990s/2000s, the lands that remained without claimants were re-appropriated by farmers or pastoralists. In some cases, people would advance their land claims in the form of customary rights of occupancy under adverse possession according to the Village Land Act 1999, having used abandoned land for more than 12 years. However, their claims and land rights have often not been recognized formally (Chachage \& Mbunda, 2009) and years later new investors would purchase the contested lands by paying the former - officially recognized - owners, and attempting to evict the farmers or pastoralists. Examples 
are a sugar plantation in Bagamoyo (Chung, 2017), a rice plantation in Kilombero (Maganga et al., 2016), and a tourism lodge and investment in Loliondo (Gardner, 2016).

The case of Kilombero is particularly insightful in illustrating how multiple and intersecting authoritative claims to land can converge into a powerful bulwark against the most vulnerable and marginalized groups. In 2006-7 the government evicted thousands of pastoralists from the Usangu wetlands that were then incorporated into the Ruaha National Park. At least 15 villages had to be 'moved' to make space for the park. According to Walsh (2012, p. 323), the expansion of the park was pushed by a small group of wellconnected tourism investors that effectively lobbied the central government to evict pastoralists by 'disseminating the degradation narratives and fuelling the environmental panic'. Many of the displaced people and their livestock ended up in the Kilombero valley. Kilombero had already been designated a Game Controlled Area (GCA) and a Ramsar site under the international Wetland Convention ${ }^{24}$. Backed by the 2009 Wildlife Conservation Act, which introduced stringent restrictions on human activities in Game Controlled Areas, the state-run research institute TAWIRI ${ }^{25}$ concluded that cultivation and settlement - 51.4 \% of land use in the Kilombero valley in 2009 - were 'incompatible' with the GCA designation (TAWIRI, 2011, cited in URT, 2013b). Within the scope of Ramsar, 29 villages in the Kilombero and Ulanga districts had to prepare restrictive village land use plans (Axberg et al., 2011; Greco, 2016) that in 2011-12 culminated in evictions in line with the 2009 Wildlife Conservation Act (URT, 2013b). Soon thereafter, in 2013, the international consulting firm ERM conducted environmental and social impact studies for SAGCOT in, among other places, the Kilombero valley (ERM, 2013; URT, 2013b). With reference to the earlier TAWIRI report, ERM highlighted how 'the designation of the floodplain and surrounding areas as a

\footnotetext{
${ }^{24}$ Ramsar sites are managed by the Wildlife Division of the Ministry of Natural Resources and Tourism. Ramsar sites overlap with village lands, Game Controlled Areas, Game Reserves and Forest Reserves, lakes and Marine Parks, representing an additional layer of land and water protection against subsistence use (see Table 3, Figure 4)

${ }^{25}$ Tanzania's Wildlife Research Institute
}

This article is protected by copyright. All rights reserved. 
Game Controlled Area, and also as a Ramsar Site, has seemingly had very little deterrent effect on encroachment' (URT, 2013b, p. 163). ERM staff also pointed out that efforts to evict pastoralists from Kilombero were not accompanied by a plan to identify an alternative location for the displaced (ERM, 2013). The most recent report on vulnerable groups and social impacts of SAGCOT - issued by the Prime Minister's office in 2016 - omitted any references to Usangu evictions as reasons for immigration into Kilombero, and it failed to include the recent evictions from Kilombero (URT, 2016b). The same year, repeated calls to protect the 'national heritage' against 'invaders' were issued by regional government authorities (Guardian, 2016a).

Another prominent case of the interlocking nature of land alienation centres around the plight of Barabaig pastoralists, whose homeland in Hanang District was appropriated by a Canadian-Tanzanian wheat investment scheme in the 1980s and '90s (Lane, 1994). The Barabaig have, since then, struggled to find other lands for livestock grazing and watering. In response to land alienation, some Barabaig have settled in neighbouring Babati District close to Lake Manyara, where their resident status is currently challenged by a European ecotourism investor and a village government in the context of community-based conservation, known as Burunge Wildlife Management Area (Bluwstein, 2017). Other Barabaig migrated to Bagamoyo District, where a Swedish company was promised land for sugar cane production in 2006. Years before the official allocation of 20,000 ha to the company in 2013 , this investment intensified conflicts among Barabaig pastoralists, other pastoral groups and farmers present in the area. Eventually, the investment has stalled and failed to plant any sugar cane. In November 2016 the Ministry of Lands, Housing and Human Settlements Development revoked the investor's title deed. This exemplifies that deals that do not materialize and fail to produce, can also lead to land alienation (Chung, 2017). In another and similar case, both farmers and immigrant Sukuma pastoralists were dispossessed of land and water access due to a stalled biofuel-food investment project in Kigoma (Engström, 2013).

This article is protected by copyright. All rights reserved. 
Yet another example illustrates the historical amnesia by conservationists who often perceive people living adjacent to protected areas as a threat, with little regard to histories of dispossession and land alienation that contribute to migration and land conversion to agriculture. Markus Borner, the former director of Frankfurt Zoological Society, a prominent German conservation NGO, published an influential paper in 1985 suggesting that due to human activities such as agriculture taking place around Tarangire National Park in Northern Tanzania, Tarangire is becoming an 'isolated "island" park' for resident species only (Borner, 1985, p. 91). Some of the land conversion to agriculture was due to immigration of displaced farmers from the slopes of Mount Meru and Kilimanjaro to make space for European coffee plantations and national parks (Igoe, 2008). Regardless, Borner recommended to ban agriculture across $6,000 \mathrm{~km}^{2}$ around the park and to destock the Maasai. Thus, previous dispossession and land alienation taking place hundreds of kilometres away (around Meru and Kilimanjaro) created, years later, new justifications for land control and alienation in a new area (around Tarangire).

We have not touched upon land alienation in the wake of the establishment of refugee camps. However, as recently as in 2000, Tanzania hosted the largest population of refugees on the African continent with over 680,000 people from DRC, Burundi and Rwanda. ${ }^{26}$ Refugee camps were established across Kigoma and Kagera regions on land that was in most cases acquired from villages and converted into general land. Camps operated by the UNHCR have all resulted in land loss to local communities and were not returned to the villagers even after most camps were eventually shut down (although recently some had to reopen due to the continuing conflict in Burundi). More research is needed to better determine the extent of land alienation in these cases.

26 “Tanzanian refugee numbers drops below 100,000: UN," UNHCR/REFDAILY, 29 Nov 2009. Accessed at: http://www.unhcr.org/cgi-bin/texis/vtx/refdaily?pass=52fc6fbd5\&id=4b13767b5. Also "Tanzania opens new camps for Burundian refugees to ease conditions in Nyarugusu Camp," UNHCR, 7 Oct 2015. Accessed at: http://www.unhcr.org/56153da96.html 
In response to dispossession, many pastoralists and farmers diversify their income sources, continue migrating to other parts of the country, or turn to urban areas in search for wage labour (McCabe et al., 2014; May \& Ikayo, 2007; Nyenza, Nzunda, \& Katani, 2013). However, the nascent formal labour market in Tanzania absorbs only a fraction of those searching for work (Wuyts \& Kilama, 2016). The growing tensions between farmers and pastoralists, pastoralists and conservationists, or farmers and conservationists are exemplifying this development. To what degree are human population growth and migration intertwined with the processes of land alienation and associated land conflicts that we have illustrated so far? Given the population projections as previously discussed, most Tanzanians will continue to depend on land as their primary means of (re)production due to lack of alternatives, although making a living in rural areas is becoming increasingly difficult for many (Coulson, 2013; Patnaik \& Moyo, 2011). Coulson (2013) suggests that two opposing processes take place in Tanzania in parallel (and may be spatially unevenly distributed) and will likely decide the future of Tanzania' peasantry: on one hand agricultural innovation can to some degree counteract population growth and a decreasing land availability (see Boserup, 1965), while on the other hand deagrarianization (see Bryceson's work) is another response to decreasing land availability and reduced agricultural productivity. While it is difficult to pass a definite judgement on which of the two processes currently prevails, rural-urban and rural-rural migration dynamics and widespread land conflicts suggest that, in a context of projected population growth and a jobless economic growth, an increasingly land-deprived peasantry will suffer growing hardship in the future.

\section{CONCLUSION}

Contrary to claims of unused land, we assert that the overall land pressure in Tanzania has increased substantially over the past 1-2 decades. Reinforced by continual land dependency of the rural population, population growth and increasing social differentiation, this development is a consequence of Tanzania's

This article is protected by copyright. All rights reserved. 
embracement of neoliberal policies to attract, enable and facilitate foreign and domestic investment for conservation and tourism, mining and agriculture. Historical and present data on land under conservation, medium- or large-scale agriculture, and mining are incomplete and to some extent ambiguous. Moreover, many land tenure reconfigurations that we describe cannot be simply conceptualized, measured, and counted as physical land grabs. Rather, the rush to land use planning and titling, and pastoral and labour migration patterns are indicators of often indirectly experienced effects of an ongoing and incomplete primitive accumulation. Accumulation by dispossession takes many forms. It may result in a complete alienation of land, or it may also present itself in the form of restrictions on the uses of land as a means of production. The processes underlying land alienation are underpinned by uneven power relations that particularly affect poor and female-headed households pertaining to land access and resource control. The effects further extend into the patriarchal household, leading to a locally specific and a priori unpredictable re-negotiation of gender roles and relations in the wake of commercial agriculture, mining or conservation interventions (Chung, 2017; Bryceson \& Jønsson, 2010; Brockington, 2002). Of course, land tenure reconfigurations do not go unchallenged as some examples of failed investments in large-scale agriculture or stalled implementations of wildlife management areas or hunting concessions demonstrate.

While the localized effects of all these reconfigurations are geographically contingent, unevenly distributed and not always associated with foreign investment, they jointly contribute further to a growing land pressure in Tanzania. As shown in this article, exclusive attention to foreign investment or a particular sector (such as agriculture) would unnecessarily narrow the analysis. Instead, an aggregated view across sectors, actors, institutions, time and scales is needed to appreciate the interlocking nature of different processes of land alienation. The ongoing scramble for land that we see unravelling in Tanzania pushes land-dependent yet land-deprived people to respond in ways that to many only at face value look like 
voluntary choices, but can further undermine the conditions of land-based reproduction ${ }^{27}$. Local processes of land alienation mutually reinforce one another, amplifying land tenure reconfigurations that at an aggregate scale mean growing land pressure overall. With these various processes jointly contributing to a scramble for land that is felt in many localities across Tanzania, we can begin to see a 'simple reproduction squeeze' (Bernstein, 1977), whereby the most vulnerable groups - rural poor, migrants, women, youth, pastoralists - find it increasingly difficult to maintain or increase their consumption and production. This may, in turn, lend support to claims that rural livelihoods are less productive than large-scale investments, thereby further entrenching the arguments for land tenure changes that adversely affect vulnerable smallholders, who become increasingly trapped between land dependence and land deprivation.

Ultimately, official policy objectives of poverty alleviation and inclusive development through land use planning, land tenure formalization, agricultural commercialization, mineral extraction and communitybased conservation and tourism will fail, as long Tanzania's political economy advances an uneven development through land alienation.

\section{REFERENCES}

Abdallah, J., Engström, L., Havnevik, K., \& Salomonsson, L. (2014). Large-scale land acquisitions in Tanzania: A critical analysis of practices and dynamics. In The Global Land Grab. Beyond the Hype, edited by M. Kaag and A. Zoomers, pp 36-53.: London: ZED books.

Akram-Lodhi, A. H. (2007). Land, Markets and Neoliberal Enclosure: An Agrarian Political Economy Perspective. Third World Quarterly 28 (8):1437-56.

Angelsen, A., Jagger, P., Babigumira, P.R., Belcher, B., Hogarth, N.J., Bauch, S., Börner, J., Smith-Hall, C., \& Wunder, S. (2014). Environmental Income and Rural Livelihoods: A Global-Comparative Analysis. World Development 64, Supplement 1:S12-S28.

Anseeuw, W., Boche, M., Breu, T., Giger, M., Lay, J., Messerli, P., \& Nolte, K. (2012). Transnational land deals for agriculture in the global South. Analytical Report based on the Land Matrix Database. April 2012. Bern, Montpellier, Hamburg: CDE/CIRAD/GIGA

\footnotetext{
${ }^{27}$ In the Indonesian context Tania Li describes a similar apparently self-determined process of individualization of land rights and formalization of capitalist relations from below, where smallholders themselves are taking initiatives to improve their condition ( $\mathrm{Li}, 2014)$. To $\mathrm{Li}$, the tragedy is that many do not become incorporated into commercial production but cannot go back to a 'past condition' either, becoming a surplus population without land.
} 
Askew, K., \& Odgaard, R. (in review). Title Deeds and Misdeeds: Women's Land Rights and Formalization in Tanzania, submitted to New Left Review

Axberg, G.N., Ngaga, Y.M., Maganga, F.P., \& Virtanen, P. (2011). Strategic planning of Finnish support to forestry in Tanzania. Final Report, 21 August 2011.

Baijukya, F. P., de Ridder, N., Masuki, K.F., \& Giller, K.E. (2005). Dynamics of banana-based farming systems in Bukoba district, Tanzania: changes in land use, cropping and cattle keeping. Agriculture Ecosystems \& Environment 106 (4):395-406.

Benjaminsen, T. A., Goldman, M.J., Minwary, M.Y., \& Maganga, F.P. (2013). Wildlife Management in Tanzania: State Control, Rent Seeking and Community Resistance. Development and Change 44 (5):1087-109.

Bernstein, H. (1977). Notes on capital and peasantry. Review of African Political Economy 4 (10):60-73.

Blomley, T., \& Iddi, S. (2009). Participatory forest management in Tanzania: 1993-2009 - Lessons learned and experiences to date. Unpublished report. Dar es Salaam: Forestry and Beekeeping Division, Ministry of Natural Resources and Tourism.

Bluwstein, J. (in review). From Colonial Fortresses to Neoliberal Landscapes in Northern Tanzania: a Biopolitical Ecology of Wildlife Conservation.

Bluwstein, J. (2017). Creating ecotourism territories: Environmentalities in Tanzania's community-based conservation. Geoforum 83:101-13.

Bluwstein, J., \& Lund, J.F. (2018). Territoriality by Conservation in the Selous-Niassa Corridor in Tanzania. World Development 101: 453-465.

Bluwstein, J., Moyo, F., \& Kicheleri, R. (2016). Austere Conservation: Understanding Conflicts over Resource Governance in Tanzanian Wildlife Management Areas. Conservation and Society 14 (3):218-31.

Boerstra, B. (2017). Internal territorialities. The role of law and conservation in state-citizen relations in Tanzania. Unpublished MSc thesis, University of Copenhagen

Borner, M. (1985). The increasing isolation of Tarangire National Park. Oryx 19 (02):91-6.

Borras Jr, S. M., \& Franco, J. (2012). Global land grabbing and trajectories of agrarian change: A preliminary analysis. Journal of Agrarian Change 12 (1):34-59.

Brockington, D. (2002). Fortress Conservation: The Preservation of the Mkomazi Game Reserve, Tanzania, African Issues. Indiana University Press: The International African Institute. James Currey.

Brockington, D. (2006). The politics and ethnography of environmentalisms in Tanzania. African Affairs 105 (418):97-116.

Brockington, D., \& Igoe, J. (2006). Eviction of Conservation: A Global Overview. Conservation \& Society 4 (3):46.

Brockington, D., Sachedina, H. \& Scholfield, K. (2008). Preserving the New Tanzania: Conservation and Land Use Change. International Journal of African Historical Studies 41 (3):22.

Bryceson, D. F. (2002). The scramble in Africa: reorienting rural livelihoods. World Development 30 (5):72539.

Bryceson, D. F. \& Jønsson, J. B. (2010). Gold digging careers in rural East Africa: Small-scale miners' livelihood choices. World Development 38 (3):379-92.

Bryceson, D. F. \& Geenen, S. (2016). Artisanal frontier mining of gold in Africa: labour transformation in Tanzania and the Democratic Republic of Congo. African Affairs 115 (459):296-317.

Cáceres, D. M. (2015). Accumulation by Dispossession and Socio-Environmental Conflicts Caused by the Expansion of Agribusiness in Argentina. Journal of Agrarian Change 15 (1):116-47. 
Chachage, C., \& Mbunda, R. (2009). The state of the then NAFCO, NARCO and absentee landlords' farms/ranches in Tanzania. 14 February 2009. Land rights research and resources institute, Dar es Salaam: LARRRI/HAKIARDHI.

Charnley, S. (1997). Environmentally-Displaced Peoples and the Cascade Effect: Lessons from Tanzania. Human Ecology 25 (4):593-618.

Chung, Y.B. (2017). Engendering the New Enclosures: Development, Involuntary Resettlement and the Struggles for Social Reproduction in Coastal Tanzania. Development and Change 48 (1):98-120.

Clay, N. (2016). Producing hybrid forests in the Congo Basin: A political ecology of the landscape approach to conservation. Geoforum 76:130-41.

Coulson, A. (2013). Tanzania: A Political Economy. Oxford: OUP.

DailyNews (2013). Develop it or give it back, idle land hoarders told. Tanzania Daily News. https://24tanzania.com/develop-it-or-give-it-back-idle-land-hoarders-told/.

Economist (2016). Africa's real land grab. Never mind foreign interlopers. African urbanites are scooping up more land. 23rd July 2016. The Economist. http://www.economist.com/news/middle-east-andafrica/21702472-never-mind-foreign-interlopers-african-urbanites-are-scooping-up-more.

Emel, J., Huber, M. T., \& Makene, M. H. (2011). Extracting sovereignty: Capital, territory, and gold mining in Tanzania. Political Geography 30 (2):70-9.

Engström, L. (2013). Contradictory biofuel investments. April, 17, 2013. The Nordic Africa Institute.

ERM (Environmental Resources Management) 2013. SAGCOT Environmental and Social Management Framework (ESMF). Consultant report for the Government of Tanzania.

FAO (Food and Agricultural Organization of the United Nations) 2014. Tanzania Country Fact Sheet on Food and Agriculture Policy Trends. September 2014. Rome: FAO

Ferguson, J. (2013). Declarations of dependence: labour, personhood, and welfare in southern Africa. Journal of the Royal Anthropological Institute 19 (2):223-42.

Gardner, B. (2016). Selling the Serengeti: The Cultural Politics of Safari Tourism: University of Georgia Press.

Gardner, B. (2012). Tourism and the politics of the global land grab in Tanzania: markets, appropriation and recognition. The Journal of Peasant Studies 39 (2):377-402.

Geisler, C. (2012). New Terra Nullius Narratives and the Gentrification of Africa's "Empty Lands". Journal of World Systems Research 18(1):15-29.

Glassman, J. (2006). Primitive accumulation, accumulation by dispossession, accumulation by 'extraeconomic' means. Progress in Human Geography 30 (5):608-25.

Goldman, M. J. (2009). Constructing Connectivity: Conservation Corridors and Conservation Politics in East African Rangelands. Annals of the Association of American Geographers 99 (2):335-59.

Goldman, M. J., \& Riosmena, F. (2013). Adaptive capacity in Tanzanian Maasailand: Changing strategies to cope with drought in fragmented landscapes. Global Environmental Change 23 (3):588-97.

Gray, H. (2013). Industrial policy and the political settlement in Tanzania: aspects of continuity and change since independence. Review of African Political Economy 40 (136):185-201.

Greco, E. (2015). Landlords in the making: class dynamics of the land grab in Mbarali, Tanzania. Review of African Political Economy 42 (144):225-44.

Greco, E. (2016). Village land politics and the legacy of ujamaa. Review of African Political Economy 43 (sup1):22-40.

Green, K. E., \& Adams, W.A. (2014). Green grabbing and the dynamics of local-level engagement with neoliberalization in Tanzania's wildlife management areas. The Journal of Peasant Studies 42 (1):97117. 
Green, K. E., \& Lund, J. F. (2015). The politics of expertise in participatory forestry: a case from Tanzania. Forest Policy and Economics 60:27-34.

Guardian (2016a). Evict invading pastoralists, farmers on wetlands. IPP Media. http://ippmedia.com/en/news/evict-invading-pastoralists-farmers-wetlands.

Guardian (2016b). PM orders seizure of undeveloped land." IPP Media, online not available anymore.

Hall, D., Hirsch, P., \& Li, T. (2011). Powers of Exclusion: Land Dilemmas in Southeast Asia: NUS Press Singapore.

Hall, D. (2013). Primitive Accumulation, Accumulation by Dispossession and the Global Land Grab. Third World Quarterly 34 (9):1582-604.

Hall, R., Scoones, I., \& Tsikata, D. (2015). Africa's Land Rush: Rural Livelihoods \& Agrarian Change: James Currey.

Harvey, D. (2003). The New Imperialism. Oxford: OUP .

Hodgson, D. L., \& Schroeder, R. A. (2002). Dilemmas of counter-mapping community resources in Tanzania. Development and Change 33 (1):79-100.

Hodgson, D.L. (2001). Once Intrepid Warriors: Gender, Ethnicity, and the Cultural Politics of Maasai Development. Bloomington: Indiana University Press.

Homewood, K., Nielsen, M.R., \& Keane A. (in review). Women, Wellbeing and Wildlife Management Areas in Tanzania. World Development

Holterman, D. (2014). Slow violence, extraction and human rights defence in Tanzania: Notes from the field. Resources Policy 40:59-65.

Huggins, C. D. (2014). 'Control Grabbing' and small-scale agricultural intensification: emerging patterns of state-facilitated 'agricultural investment' in Rwanda. The Journal of Peasant Studies 41 (3):365-84.

Hunsberger, C., Corbera, E., Borras, S. M., Franco, J. C., Woods, K., Work, ... Vaddhanaphuti, C. (2017). Climate change mitigation, land grabbing and conflict: towards a landscape-based and collaborative action research agenda. Canadian Journal of Development Studies:1-20.

Hurst, A. W. (2004). Not Yet Out of the Woods: A Political Ecology of State Forest Policy and Practice in Mainland Tanzania, 1961-1998. PhD thesis, University of Oxford.

Igoe, J., \& Brockington, D. (1999). Pastoral Land tenure and Community Conservation: a Case Study from North-East Tanzania. Pastoral Land Tenure Series No. 11, London: IIED.

Igoe, J., \& Brockington, D. (2007). Neoliberal Conservation: A Brief Introduction. Conservation \& Society 5 (4):432-49.

Igoe, J., \& Croucher, B. (2007). Conservation, Commerce, and Communities: The Story of Community-Based Wildlife Management Areas in Tanzania's Northern Tourist Circuit. Conservation \& Society 5 (4):534-61.

Igoe, J. (2008). National Parks and Human Ecosystems. The Challenge to Community Conservation. A Case Study from Simanjiro, Tanzania. Conservation and Mobile Indigenous Peoples, 77-96.

Jayne, T.S., Chamberlin, J., Traub, L., Sitko, N., Muyanga, M., Yeboah, K., . . Kachule, R. (2016). Africa's changing farm size distribution patterns: the rise of medium-scale farms. Agricultural Economics 47: 197-214.

Kangalawe, R. Y. M., Christiansson, C., \& Östberg, W. (2008). Changing land-use patterns and farming strategies in the degraded environment of the Irangi Hills, central Tanzania. Agriculture, ecosystems \& environment 125 (1):33-47.

Kelly, A. B. (2011). Conservation practice as primitive accumulation. The Journal of Peasant Studies 38 (4):683-701. 
Khatun, K., Gross-Camp, N., Corbera, E., Martin, A., Ball, S., \& Massao, G. (2015). When Participatory Forest Management makes money: insights from Tanzania on governance, benefit sharing, and implications for REDD+. Environment and Planning A 47 (10):2097-112.

Kisembo, P. (2012). Hunting firm illegally leased block to uranium miners. Guardian. http://eastafricanewz.blogspot.com/2012/07/hunting-firm-illegally-leased-block-to.html, IPP Media.

Kitula, A. G. N. (2006). The environmental and socio-economic impacts of mining on local livelihoods in Tanzania: A case study of Geita District. Journal of cleaner production 14 (3):405-14.

Kjekshus, H. (1977). The Tanzanian Villagization Policy: Implementational Lessons and Ecological Dimensions. Canadian Journal of African Studies 11 (2):269-82.

Knapman, C., Silici, L., Cotula, L., \& Mayers, J. (2017). Africa's farmland in changing hands. London: IIED. Korotayev, A., \& Zinkina, J. (2015). East Africa in the Malthusian Trap? Journal of Developing Societies 31 (3):385-420.

Kulindwa, K., Mashindano, F., Shechambo, F., \& Sosovele, H. (2003). Mining for Sustainable Development in Tanzania. Dar es Salaam: Dar es Salaam University Press.

Landmatrix (2016). Land Matrix. Large Scale Land Acquisitions Profile Tanzania. Accessed 2016.10.28. http://landmatrix.org.

Lane, C. (1994). Pastures lost: alienation of Barabaig land in the context of land policy and legislation in Tanzania. Nomadic Peoples 34/35:81-94.

Lange, S. (2008). Land tenure and mining in Tanzania. Bergen: Chr. Michelsen Institute.

Li, T. M. (2010). To Make Live or Let Die? Rural Dispossession and the Protection of Surplus Populations. Antipode 41:66-93.

Li, T. M. (2011). Centering labor in the land grab debate. The Journal of Peasant Studies 38 (2):281-98.

Li, T. M. (2014). Land's End: Capitalist Relations on an Indigenous Frontier. Durham: Duke University Press.

Lindberg, C. (1996). Society and Environment Eroded. A Study of Household Poverty and Natural Resource Use in Two Tanzanian Villages. PhD thesis, Uppsala University.

Locher, M. (2016). 'How come others are selling our land?' Customary land rights and the complex process of land acquisition in Tanzania. Journal of Eastern African Studies 10 (3):393-412.

Locher, M., \& Sulle, E. (2014). Challenges and methodological flaws in reporting the global land rush: observations from Tanzania. The Journal of Peasant Studies 41 (4):569-92.

Lokina, R., Nerman, M., \& Sandefur, J. (2011). Poverty \& Productivity: Small-Scale Farming in Tanzania, 1991-2007. Working paper F-40006-TZA-1, London: IGC International Growth Center.

Lund, J. F., \& Saito-Jensen, M. (2013). Revisiting the Issue of Elite Capture of Participatory Initiatives. World Development 46:104-12.

Lund, J. F., Sungusia, E., Bukhi Mabele, M. \& Scheba, A. (2017). Promising Change, Delivering Continuity: REDD+ as Conservation Fad. World Development 89:124-39.

Lund, J. F., \& Treue, T. (2008). Are We Getting There? Evidence of Decentralized Forest Management from the Tanzanian Miombo Woodlands. World Development 36 (12):2780-800.

Lunstrum, E. (2016). Green grabs, land grabs and the spatiality of displacement: eviction from Mozambique's Limpopo National Park. Area 48(2): 142-152.

Lunstrum, E., Bose, P., \& Zalik, A. (2016). Environmental displacement: the common ground of climate change, extraction and conservation. Area 48(2):130-133.

Lyimo, J. (2014). Land Use Change and Livelihood Diversification in Usangu Plains. University of Dar es Salaam Journals 34 (1-2). 
Magai, P.S., \& Márquez-Velázquez, A. (2011). Tanzania's Mining Sector and Its Implications for the Country's Development. Working Papers on Money, Finance, Trade and Development. Berlin: HTW.

Maganga, F. P., Askew, K., Odgaard, R., \& Stein, H. (2016). Dispossession through Formalization: Tanzania and the G8 Land Agenda in Africa. Asian Journal of African Studies 40:3-49.

Margulis, M. E., McKeon, N. \& Borras Jr., S. B. (2013). Land grabbing and global governance: critical perspectives. Globalizations 10 (1):1-23.

Marx, K. (1976). Capital, Volume 1. London: Penguin Classics.

May, A., \& Ikayo, F. N. O. (2007). Wearing Illkarash: Narratives of image, identity and change among maasai labour migrants in Tanzania. Development and Change 38 (2):275-98.

Mayeta, L. (2016). Status of Community Participation in Wildlife Management in Tanzania. 3rd National CBNRM Forum

McCabe, J. T., Leslie, P. W., \& DeLuca, L. (2010). Adopting Cultivation to Remain Pastoralists: The Diversification of Maasai Livelihoods in Northern Tanzania. Human Ecology 38 (3):322-U18.

McCabe, J. T., Smith, N. M., Leslie, P. W. \& Telligman, A. L. (2014). Livelihood Diversification through Migration among a Pastoral People: Contrasting Case Studies of Maasai in Northern Tanzania. Human organization 73 (4):389-400.

Meagher, K. (2016). The Scramble for Africans: Demography, Globalisation and Africa's Informal Labour Markets. The Journal of Development Studies 52 (4):483-97.

MLHS (Ministry of Lands, Housing and Human Settlements) (2012). SAGCOT Investment Partnership Program. 27 November 2012. Presentation by Hon Minister

MNRT (Ministry of Natural Resources and Tourism) (2006). Committee Task Force Report on Hunting. Unpublished report. Dar es Salaam, Tanzania

MNRT (Ministry of Natural Resources and Tourism) (2016). Mtazamo wa wizara kuhusu kupunguzwa kwa maeneo ya hifadhi nchini kwa ajili ya kuongeza malisho ya migufo. January 2016. Unpublished report, Dar es Salaam, Tanzania

Moyo, S. (2008). African Land Questions, Agrarian Transitions and the State: Contradictions of Neo-liberal Land Reforms. Dakar: Council for the Development of Social Science Research in Africa.

Moyo, S., \& Yeros, P. (2005). Reclaiming the land: The resurgence of rural movements in Africa, Asia and Latin America. London: Zed Books.

Mueller, B. E. T. (2011). The agrarian question in Tanzania: using new evidence to reconcile an old debate. Review of African Political Economy 38 (127):23-42.

Nalepa, R. A., Short Gianotti, A. G. \& Bauer, D. M. (2017). Marginal land and the global land rush: A spatial exploration of contested lands and state-directed development in contemporary Ethiopia. Geoforum 82:237-251.

NBS (National Bureau of Statistics) (2014). Basic Demographic and Socio-Economic Profile. Statistical Tables. Tanzania Mainland. April 2014. Dar es Salaam: Ministry of Finance.

Nelson, F., Sulle, E. \& Lekaita, E. (2012). Land grabbing and political transformation in Tanzania. Paper presented at the International conference on global land grabbing II.

Neumann, R.P. (1998). Imposing Wilderness: Struggles Over Livelihood and Nature Preservation in Africa. Berkeley: University of California Press.

NewAlliance (2014). Tanzania: Progress in Public Private Partnership in Agriculture Transformation. June 2014.

Noe, C. (2013). Contesting village land: uranium and sport hunting in Mbarang'andu Wildlife Management Area, Tanzania. LDPI Working Paper 15. The Land Deal Politics Initiative.

This article is protected by copyright. All rights reserved. 
Nyenza, O. M., Nzunda, E.F., \& Katani, J.Z. (2013). Socio-ecological resilience of people evicted for establishment of Uluguru nature reserve in morogoro region, Tanzania. Forests Trees and Livelihoods 22 (3):190-203.

Odgaard, R. (2002). Scrambling for land in Tanzania: Process of formalisation and legitimisation of land rights. European Journal of Development Research 14(2): 71-88.

Odgaard, R. (2006). Land rights and land conflicts in Africa: The Tanzania case. Copenhagen: Danish Institute for International Studies.

Olwig, M. F., Noe, C., Kangalawe, R. \& Luoga, E. (2015). Inverting the moral economy: the case of land acquisitions for forest plantations in Tanzania. Third World Quarterly 36 (12):2316-36.

Oya, C. (2012). Contract Farming in Sub-Saharan Africa: A Survey of Approaches, Debates and Issues. Journal of Agrarian Change 12 (1):1-33.

Oya, C. (2013). The land rush and classic agrarian questions of capital and labour: A systematic scoping review of the socioeconomic impact of land grabs in Africa. Third World Quarterly 34 (9):1532-57.

Packer, C. (2015). Lions in the Balance: Man-Eaters, Manes, and Men with Guns. Chicago: University of Chicago Press.

Patnaik, U., \& Moyo, S. (2011). The Agrarian Question in the Neoliberal Era: Primitive accumulation and the peasantry. Fahamu/Pambazuka.

Pedersen, R. H. (2015). A Less Gendered Access to Land? The Impact of Tanzania's New Wave of Land Reform. Development Policy Review 33(4): 415-432.

Pedersen, R.H., \& Jacob, T. (2017). Reconfigured state-community relations in Africa's extractive sectors: insights from post-liberalisation Tanzania. The Extractive Industries and Society 4(4): 915-922

Peluso, N.L., \& Lund, C. (2011). New frontiers of land control: Introduction. The Journal of Peasant Studies $38(4): 667-81$.

Peters, P. E. (2004). Inequality and social conflict over land in Africa. Journal of Agrarian Change 4 (3):269314.

Peters, P.E. (2013). Land appropriation, surplus people and a battle over visions of agrarian futures in Africa. Journal of Peasant Studies 40 (3):537-62.

Ponte, S. (2001). Trapped in Decline? Reassessing Agrarian Change and Economic Diversification on the Uluguru Mountains, Tanzania. The Journal of Modern African Studies 39 (1):81-100.

Prudham, S. (2007). The Fictions of Autonomous Invention: Accumulation by Dispossession, Commodification and Life Patents in Canada. Antipode 39 (3):406-29.

Richter, R. E. (1994). Landnutzungskonflikte in den Weidegebieten Tanzanias: Die Geschichte der fortschreitenden Entrechtung der Maasai seit dem Beginn der Kolonialzeit. Africa Spectrum 29 (3):265-84.

Sachedina, H. (2008). Wildlife is Our Oil: Conservation, Livelihoods and NGOs in the Tarangire Ecosystem, Tanzania. PhD thesis, University of Oxford.

SAGCOT (Southern Agricultural Growth Corridor Tanzania) (2011). Southern Agricultural Growth Investment Corridor of Tanzania. Investment Blueprint. Dar es Salaam: SAGCOT

Schroeder, R. A. (2012). Africa after Apartheid : South Africa, Race, and Nation in Tanzania. Bloomington, IN: Indiana University Press.

Scoones, I., Hall, R., Borras, S. M., White, B., \& Wolford, W. (2013). The politics of evidence: methodologies for understanding the global land rush. The Journal of Peasant Studies 40 (3):469-83.

Shao, J. (1986). The Villagization Program and the Disruption of the Ecological Balance in Tanzania. Canadian Journal of African Studies 20 (2):219-39. 
Shekighenda, L. (2016). Pastoralists told 'out of reserves'. October 12, 2016. In Tanzania Daily News. http://allafrica.com/stories/201610120040.html.

Shivji, I.G. (1998). Not Yet Democracy: Reforming Land Tenure in Tanzania. Dar es Salaam: IIED, HAKIARDHI, Faculty of Law, University of Dar es Salaam.

Shivji, I. G. (2009). Accumulation in an African periphery: a theoretical framework. Dar es Salaam: Mkuki na Nyota Publishers.

Snyder, K. A. (1996). Agrarian change and land-use strategies among Iraqw farmers in northern Tanzania. Human Ecology 24 (3):315-40.

Sosovele, H. (2015). A snapshot of recent WMA Assessment Reports, WMA Stakeholders Workshop, 2.7.2015

Stein, H., \& Cunningham, S. (2017). Formalization and Land grabbing in Africa: Facilitation or Protection? Tanzania Journal of Development Studies 15 (1\&2)

Stein, H., Maganga, F., Odgaard, R., Askew, K., \& Cunningham, S. (2016). The Formal Divide: Customary Rights and the Allocation of Credit to Agriculture in Tanzania. The Journal of Development Studies 52(9):1306-1319.

Sulle, E. (2015). Land Grabbing and Agricultural Commercialization Duality: Insights from Tanzania's Transformation Agenda. In The New Harvest. Agrarian Policies and Rural Transformation in Souhern Africa, edited by D Chinigo. Afriche e orienti.

Sundet, G. (2005). The 1999 Land Act and Village Land Act. A technical analysis of the practical implications of the Acts. Working Draft.

Sundet, G. (1997). The politics of land in Tanzania. PhD thesis, University of Oxford.

Sungusia, E., \& Lund, J. F. (2016). Against all policies: Landscape level forest restoration in Tanzania. World Development Perspectives 3:35-7.

Sunseri, T. (2009). Wielding the Ax: State forestry and social conflict in Tanzania, 1820-2000, Athens: Ohio University Press.

Tairo, A. (2014). Tanzania gives go ahead to uranium mining in Selous Game Reserve. 13 May 2014. In ETN Global Travel Industry News. http://www.eturbonews.com/45745/tanzania-gives-go-aheaduranium-mining-selous-game-reserve.

TFCG (Tanzania Forest Conservation Group) (2017) Arc Journal 30, Special Issue on Tanzania's Nature Reserves.

UNEP-WCMC (United Nations Environment Programme-World Conservation Monitoring Centre) (2017). Protected Area Profile for United Republic of Tanzania, World Database of Protected Areas, www.wdpa.org/country/TZ, Accessed 2017.01.17

URT (United Republic of Tanzania) (1994). Report of the Presidential Commission of Inquiry Into Land Matters. Volume I. Land policy and land tenure structure. Uddevalla, Sweden. Dar es Salaam: Ministry of Lands, Housing, and Urban Development.

URT (United Republic of Tanzania) (1997). National Land Policy 1995. Second Edition. Dar es Salaam: Ministry of Lands and Human Settlements.

URT (United Republic of Tanzania) (1999). Land Act No. 4. Dar es Salaam.

URT (United Republic of Tanzania) (2009). Wildlife Conservation Act No.5 of 2009. Dar es Salaam.

URT (United Republic of Tanzania) (2010). Private Sector Competitiveness Project. Dar es Salaam: Ministry of Lands, Housing and Human Settlements Development.

URT (United Republic of Tanzania) (2012a). Large Scale Farms National Census 2007-8. Report, 26 June 2012. Dar es Salaam. 
URT (United Republic of Tanzania) (2012b). Participatory Forest Management: Facts and Figures. December 2012. Dar es Salaam: Ministry of Natural Resources and Tourism.

URT (United Republic of Tanzania) (2013a). An assessment and evaluation of ownership of farms above 50 acres in Tanzania mainland. Draft report prepared by Department of Economics, University of Dar es Salaam. Dar es Salaam: Ministry of Land, Housing and Human Settlements.

URT (United Republic of Tanzania) (2013b). SAGCOT Strategic Regional Environmental and Social Assessment (SRESA). Consultant report by ERM. Prime Minister's Office.

URT (United Republic of Tanzania) (2013c). Wildlife Sub-Sector Statistical Bulletin. 2013 Second Edition. Dar es Salaam: Ministry of Natural Resources and Tourism.

URT (United Republic of Tanzania) (2013d). National Strategy for REDD+. February 2013, Dar es Salaam.

URT (United Republic of Tanzania) (2014). Tanzania Forest Service Agency, Three Year Implementation Report 2011-2014, Dar es Salaam: Ministry of Natural Resources and Tourism.

URT (United Republic of Tanzania) (2015). Tanzania Mining Industry Tanzania Mining Industry Investor's Guide. June 2015. Dar es Salaam: Ministry of Energy and Minerals.

URT (United Republic of Tanzania) (2016a). The National Land Policy 2016. Draft. For external consultations with stakeholders. Dar es Salaam: Ministry of Lands, Housing and Human Settlements.

URT (United Republic of Tanzania) (2016b). SAGCOT Environmental and Social Management Framework (ESMF). Updated Vulnerable Groups Planning Framework (VGPF). Prime Minister's Office.

von Freyhold, M. (1979). Ujamaa villages in Tanzania: analysis of a social experiment. Norfolk: Fakenham Press Ltd

Vyamana, V. G. (2009). Participatory forest management in the Eastern Arc Mountains of Tanzania: who benefits? International Forestry Review 11 (2):239-53.

Walsh, M. (2012). The not-so-Great Ruaha and hidden histories of an environmental panic in Tanzania. Journal of Eastern African Studies 6 (2):303-35.

Walwa, W. (2017). Land use plans in Tanzania: repertoires of domination or solutions to rising farmerherder conflicts? Journal of Eastern African Studies, 1-17.

Wolford, W., Borras, S. M., Hall, R., Scoones, I., \& White, B. (2013). Governing Global Land Deals: The Role of the State in the Rush for Land. Development and Change 44 (2):189-210.

Wood, E. M. (2002). The Origin of Capitalism. A Longer View. Verso.

Wright, V. C. (2016). Turbulent times: fighting history today in Tanzania's trophy hunting spaces. Journal of Contemporary African Studies 34 (1):40-60.

Wuyts, M., \& Kilama, B. (2016). Planning for Agricultural Change and Economic Transformation in Tanzania? Journal of Agrarian Change 16 (2):318-41.

This article is protected by copyright. All rights reserved. 


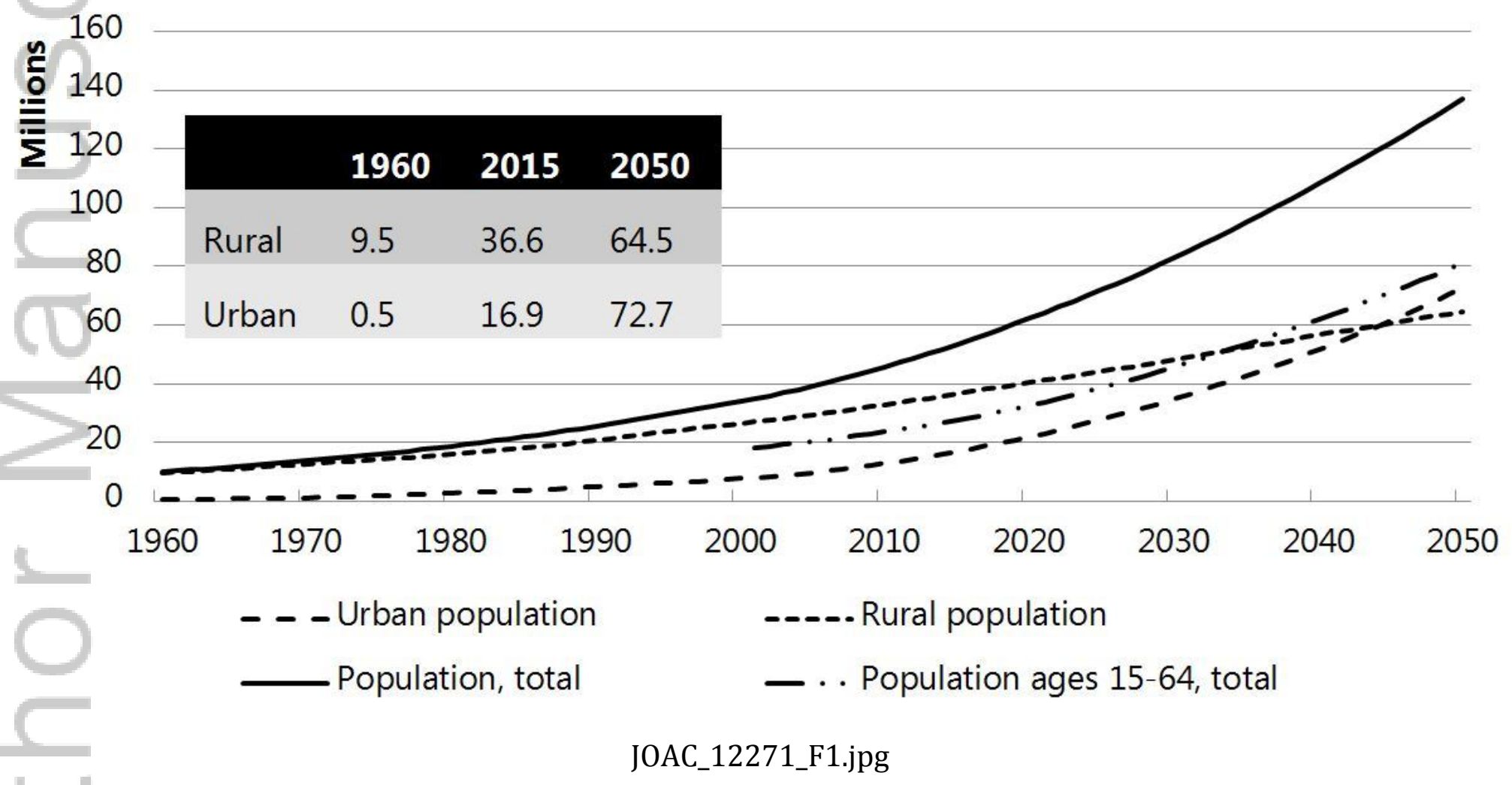

This article is protected by copyright. All rights reserved. 


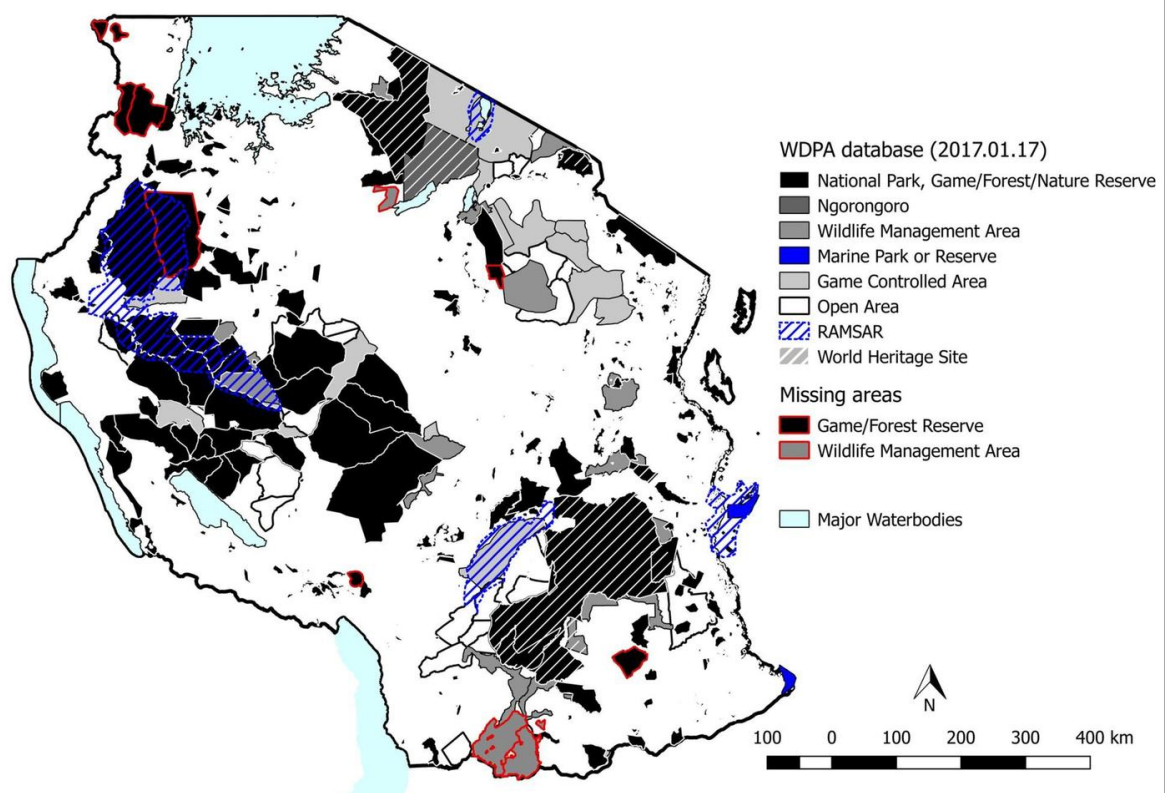

JOAC_12271_F4.jpeg

This article is protected by copyright. All rights reserved. 